\title{
Chemotherapy and oncolytic virotherapy: advanced tactics in the war against cancer
}

\section{Andrew Nguyen, Louisa Ho and Yonghong Wan*}

Department of Pathology and Molecular Medicine, McMaster Immunology Research Centre, McMaster University, Hamilton, ON, Canada

\section{Edited by:}

Volker Schirrmacher, German Cancer

Research Center, Germany

\section{Reviewed by:}

Amedeo Amedei, University of

Florence, Italy

Pedro Berraondo, Centro de

Investigación Médica Aplicada, Spain

*Correspondence:

Yonghong Wan, Department of Pathology and Molecular Medicine,

McMaster Immunology Research

Centre, McMaster University, 1200

Main Street West, Hamilton, ON L8N

3Z5, Canada

e-mail:wanyong@mcmaster.ca
Cancer is a traitorous archenemy that threatens our survival. Its ability to evade detection and adapt to various cancer therapies means that it is a moving target that becomes increasingly difficult to attack. Through technological advancements, we have developed sophisticated weapons to fight off tumor growth and invasion. However, if we are to stand a chance in this war against cancer, advanced tactics will be required to maximize the use of our available resources. Oncolytic viruses (OVs) are multi-functional cancer-fighters that can be engineered to suit many different strategies; in particular, their retooling can facilitate increased capacity for direct tumor killing (oncolytic virotherapy) and elicit adaptive antitumor immune responses (oncolytic immunotherapy). However, administration of these modified OVs alone, rarely induces successful regression of established tumors. This may be attributed to host antiviral immunity that acts to eliminate viral particles, as well as the capacity for tumors to adapt to therapeutic selective pressure. It has been shown that various chemotherapeutic drugs with distinct functional properties can potentiate the antitumor efficacy of OVs. In this review, we summarize the chemotherapeutic combinatorial strategies used to optimize virally induced destruction of tumors. With a particular focus on pharmaceutical immunomodulators, we discuss how specific therapeutic contexts may alter the effects of these synergistic combinations and their implications for future clinical use.

Keywords: oncolytic virotherapy, cancer immunotherapy, cancer vaccines, combination therapy, drug therapy, combination, oncolytic viruses
Do not repeat the tactics, which have gained you one victory, but let your methods be regulated by the infinite variety of circumstances.

-Sun Tzu, The Art of War

\section{INTRODUCTION}

Oncolytic viruses (OVs) can selectively infect, replicate in, and kill tumor cells with minimal impact on normal tissue. These tumor-specific properties, called oncotropism, is dependent on the expression of surface receptors that allow viral binding and entry, as well as, the permissiveness of the tumor cell toward viral replication. Genetic manipulation of the viral genome aims to improve the inherent therapeutic value of OVs by enhancing their capacity for targeted tumor killing $(1,2)$. Through transgene insertion, OVs can serve as directed gene-delivery vehicles, and thus accommodate a diverse array of therapeutic strategies. Arming OVs with additional weaponry, such as pro-apoptotic genes, tumor suppressors, or genes stimulating antitumor immunity, can enhance their killing capacity. With a broad arsenal, modified-OVs have the potential to target a wide spectrum of different cancer types. However, administration of OVs as a monotherapy has demonstrated varying degrees of success in clinical trials (3-5). This is likely due to host antiviral immune-mediated mechanisms that limit OV dissemination and promotes pre-mature viral clearance. Over an extended period, selective pressure on heterogeneous tumor populations can also lead to therapeutic resistance to OVs via receptor loss or mutation of essential signaling pathways required for viral replication (6). To overcome these barriers, many clinically established and novel chemotherapeutics have been used in combination with oncolytic virotherapy, showing synergistic effects that potentiate tumor killing (7-9). In this review, we summarize how immunomodulatory chemotherapeutic combinatorial strategies have been used to optimize virally induced destruction of tumors and discuss their implications for future directions and clinical use.

\section{MECHANISIMS OF ONCOLYTIC VIRUSES TUMOR TROPISM AND ONCOLYSIS}

The oncotropism of viruses is guided by cell surface receptors that enable viral binding and entry, and the permissiveness of the infected cell to viral replication. Surface receptors that are recognized by different types of viruses can be specific to neoplastic cells. These viruses target receptors characteristic of malignant phenotypes, such as Poliovirus that binds CD-155 that is almost exclusively present in high grade glioma cells $(10,11)$, and Sindbis virus that recognizes high-affinity laminin receptor overexpressed in many cancers (12). Other viruses, such as vesicular stomatitis virus (VSV) exhibit a remarkably robust and pantropic selectivity by binding to the ubiquitously expressed LDL receptor (13). Therefore, instead of relying on receptor specificity, tumor tropism of VSV is dependent on the permissiveness of malignant cells to viral infection. VSV belongs to a class of interferon (IFN)-sensitive 
viruses, which preferentially infects tissues exhibiting reduced or absent IFN responsiveness (14-17). This is a typical feature of tumors, which often acquire defects in pathways involved in innate antiviral immunity, such as the IFN pathway, as a mechanism for immune escape. In fact, many of the biological pathways altered by viral infection are similar to cellular changes acquired during carcinogenesis. For instance, mutated oncogenes such as BRAF or Cyclin A, increases the infectivity of VSV and parvovirus, respectively $(18,19)$. As well, impaired apoptotic ability typically observed in neoplastic cells provides an opportunity for OVs to enhance their replicative capacity (20).

Selective retargeting of viruses to tumor cells can also be generated in viruses without innate oncolytic abilities. Adenovirus (Ad)-based vectors are a good demonstration of this approach, since they possess a wide tropism, but a lytic life cycle that can be exploited for oncolytic virotherapy (21). One method to restrict viral replication to tumor cells is the modification of E1A and $\mathrm{E} 1 \mathrm{~B}$ genes that results in conditionally replicative Ad. As a result, selective replication occurs in cells defective in p53 or Rb tumor suppressor pathways; a characteristic observed in $50 \%$ of human cancers (22). Alternatively, various transductional retargeting strategies exist that largely involve fusing tumor targeting ligands to the Ad fiber knob domain, summarized in Ref. (23).

Viral oncolysis directly destroys tumor cells through either their lytic replication cycle or the expression of endogenous cytotoxic gene products (24). To further enhance their oncolytic effects, transgenes encoding pro-apoptotic proteins are inserted into OVs to subvert cell death machinery. These proteins include various death-inducing ligands such as TNF-related apoptosis-inducing ligand (TRAIL) $(25,26)$, Fas ligand (FasL) (27), and tumor suppressor genes (e.g., p53, p16) $(28,29)$. Alternatively, small hairpin RNA targeting factors can be inserted to silence genes involved in cell survival or proliferation, including hTERT and ki67 (30) or MYCN oncogene (31). Oncolytic viral infection can also induce autophagy, a conserved catabolic process crucial in maintaining cellular homeostasis (32). Cellular autophagy machinery is disrupted by certain viruses to facilitate its own replication $(33,34)$ and enhance oncolysis $(35,36)$. By engineering viruses to express autophagy-inducing genes, such as Beclin-1 (37) and mTOR pathway regulators $(38,39)$, improved therapeutic outcomes can be achieved. This approach may be particularly useful for treating apoptosis-resistant types of cancer, thus warranting further development toward clinical application. Lastly, some OVs can exert indirect mechanisms of tumor killing, including tumor vascular shutdown $(40,41)$ and the induction of antitumor immune responses, the latter of which is described in further detail in the following section.

\section{INDUCTION OF ANTITUMOR IMMUNE RESPONSES}

The various mechanisms through which OVs are capable of lysing cancer cells result in the release of tumor associated antigens (TAAs), proinflammatory cytokines, chemokines, and other danger signals, which facilitates immune cell recruitment and activation within tumors. In particular, activation and maturation of dendritic cells (DCs) and other antigen presenting cells (APCs) allow for efficient cross-presentation to T cells, and subsequent initiation of antitumor and antiviral immune responses
$(42,43)$. However, OVs induce only weak tumor-specific immune responses, due to premature viral clearance and immunosuppressive regulatory factors within the tumor.

To potentiate their immunogenic effects, genetic engineering strategies have been used to encode OVs with various cytokines, immunomodulators, and TAAs $(44,45)$. Evaluation of the antitumor efficacy of OVs expressing cytokines, such as IL-12, IL-2, IL-4, IL-18, IL-24, and TNF $\alpha$, has shown improved therapeutic effects (46-49). One of the most promising cytokines tested within the OV platform to date, is the granulocyte-macrophage colony-stimulating factor (GM-CSF), which promotes DC maturation and induces tumor antigen-specific cytotoxic T cells. Three major viral vectors, Ad, VV, and HSV, armed with GM-CSF have been demonstrated to enhance antitumor immunity and cytotoxicity in several clinical trials (50-57). In particular, Talimogene laherparepvec (T-VEC), a GM-CSF-expressing oHSV-1 that has recently completed phase III trials in melanoma and head and neck cancer, are the first to demonstrate efficacy of OV immunotherapy, with an approximately 30\% response rate against systemic disease, following local injection into accessible tumors $(52,53)$. Similar to GM-CSF, Fms-like tyrosine kinase-3 ligand (FLT3L) is a potent growth factor capable of recruiting and expanding DCs in vivo (58). OVs expressing FLT3L trigger DC and T cell infiltration into the tumor and enhance both antitumoral and antiviral immune responses $(42,59,60)$, implicating potential benefits of using FLT3L as an adjuvant to cancer vaccination. Another strategy to boost the antitumor response involves genetically engineering OVs to express inflammatory chemokines, and thus increasing the number of tumor-infiltrating immune cells. Expression of CCL5, CCL3, and CCL19 by OVs enhances chemotaxis of immune cells within the tumor and improves overall therapeutic benefits in vivo (61-64). Interestingly, distinct effects on virus activity were also observed, in which VV expressing CCL5 or CCL19 resulted in increased persistence within the tumor and more rapid clearance from non-tumor tissues, respectively $(61,65,66)$. Finally, crosspresentation of TAA to T cells through DC activation can also be achieved by arming OVs with co-stimulatory molecules such as CD40L $(67,68)$ and heat shock proteins $(69)$.

A more direct approach to engage antigen-specific $\mathrm{T}$ cells is to engineer OVs to express TAAs, termed oncolytic vaccines (70). As such, TAAs are overexpressed in the tumor during viral replication, thus increasing the opportunity for immune responses to be generated toward tumor-specific antigens. However, successful antitumor activity has only been reported using model tumor antigens such as OVA or $\operatorname{LacZ}(71,72)$ and the same approach was poorly effective against a self-TAA of low immunogenicity $(70,73)$. Altogether, these results suggest that overexpression of a TAA is insufficient to overcome immunosuppression in the tumor or immunodominant responses against viral antigens. Therefore, additional approaches are required to boost TAA-specific responses beyond these barriers. Indeed, significantly improved therapeutic efficacy can be achieved by adoptive transfer of TAA-specific transgenic T cells (74) or priming the host with a heterologous vector expressing the TAA (70), prior to oncolytic vaccination. Both approaches have been demonstrated to increase TAA-specific T cell frequency, by redirecting the focus of immune responses to the TAA, rather than the viral vector. Such 
OV-based cancer immunotherapies show promise by harnessing both oncolytic and antitumor immune-mediated attacks. Clinical evaluation of adoptive $\mathrm{T}$ cell transfer and OVs are currently underway as monotherapies $(4,75)$, however their success as a combination therapy has yet to be determined in human cancers.

\section{CHALLENGES OF ONCOLYTIC VIRUS MONOTHERAPY}

Oncolytic viruses as a standalone therapeutic intervention have rarely been shown to induce complete, long-term regression of established tumors in vivo $(76,77)$. Tumors can develop multiple barriers to various anticancer therapies, including oncolytic virotherapy. Here, we detail several mechanisms that may hinder the therapeutic efficacy of OVs and the challenges they pose to the development of improved cancer virotherapies.

\section{IMMUNOLOGICAL BARRIERS}

The first line of defense against viral infection is the innate immune cells that patrol, detect, and rapidly eliminate foreign invaders. DCs express pattern recognition receptors that allow for the detection and subsequent uptake of viral particles. These activated DCs then migrate to draining lymph nodes to initiate the development of adaptive immune responses and to trigger NK cell activation. NK cells have a predominant role in impeding the early spread of viruses by directly lysing virally infected cells. Together, DCs and NK cells produce a range of cytokines that promotes $\mathrm{T}$ helper 1 (Th1) cell activity and potent cytotoxic T lymphocyte (CTL) responses that are necessary for clearing virus-infected cells (78). Additionally, humoral immune responses, namely the production of neutralizing antibodies by $B$ cells and plasma cells, provide several lines of antiviral defense (79). Plasma cells derived from B1 cells imparts early defense against viral infection by producing polyspecific antibodies. CD4 ${ }^{+} \mathrm{T}$ helper cells then stimulate naive $B$ cells at later stages, in order to generate memory B cells and long-lived plasma cells that produce high amounts of specific neutralizing IgG antibodies. Finally, the complement system, composed of soluble factors and cell surface receptors, blocks viral infection by acting on both the innate and adaptive immune responses. These mechanisms include, enhancing humoral immunity, regulating antibody effector mechanisms, and modulating $\mathrm{T}$ cell function (80).

Altogether, these immunological barriers pose a particular problem for repeat administration of OVs, by further promoting the development of adaptive antiviral immunity and reducing of its oncolytic effects. Moreover, a large fraction of the population has previously been exposed to the naturally occurring viruses that are commonly employed for generating therapeutic strains. Therefore, the infectious potential of recognized OVs (e.g., Ad, HSV) becomes limited by high levels of neutralizing antibodies $(81,82)$. These circulating antibodies can limit viruses from ever reaching the tumor site, especially since some viral particles, including HSV1 - and murine leukemia virus-derived viruses, are particularly prone to inactivation by the complement system $(83,84)$.

\section{TUMOR ENVIRONMENT}

Tumors are a heterogeneous assortment of cells, composed of cancer cells, stromal cells, and infiltrating leukocytes, which promote tumor growth and maintain an immunosuppressive environment
(85). Tumor-infiltrating leukocytes (TILs) can negatively regulate immune responses within the tumor, which include regulatory T cells (Tregs), myeloid derived suppressor cells (MDSC), and type 2 macrophages (M2). Their immunosuppressive functions can be exerted by secretion of cytokines (e.g., IL-10 and TGF- $\beta$ ), through inhibitory receptors (e.g., CTLA-4 and PD-L1) via cell contact, and secretion of amino-acid depleting enzymes (arginase and IDO) in the tumor microenvironment. Tumor cells themselves also have mechanisms to suppress antitumor immunity, such as the shedding of NKG2D ligands, MICA/B that blocks NK cell and $\mathrm{T}$ cell function (86) and facilitates the expansion of immunosuppressive $\mathrm{CD}^{+}{ }^{+} \mathrm{T}$ cells $(87)$. Soluble mediators released by tumor cells can directly inhibit CTLs, which include TGF $\beta$, IL-10, $\mathrm{PGE}_{2}$, histamine, hydrogen peroxide, and adenosine (88), in addition to the hypoxic conditions and low extracellular $\mathrm{pH}$ that characterize the tumor environment $(89,90)$. Therefore, antitumor immune responses induced by modified-OVs may not be sufficient to combat a highly immunosuppressive tumor environment, unless additional therapeutic regimens are employed.

Preclinical and clinical evidence indicates that OVs often infect neoplastic lesions in a heterogeneous and incomplete fashion, irrespective of administration route and whether viruses are replication-competent or not (91-93). Physicochemical barriers to infection, including tumor size (94), the layers of dense intratumoral connective tissue (95), the elevated interstitial pressure (96), the poorly permissive vasculature (97), and the large areas of necrosis/calcification (98) play a prominent role in determining viral dissemination. As a result, oncolytic virotherapy may result in incomplete eradication of the primary tumor mass or possibly even promote metastasis of the tumor cells and eventually leading to recurrence of disease. Similar to what is observed in chemotherapy and radiotherapy regimens, malignant cells are also prone to become resistant to oncolytic virotherapy over time. This is presumably linked to the intrinsic nature of cancers to exhibit genomic instability and the propensity for accumulating mutations (99-101).

\section{COMBINING IMMUNOMODULATORY CHEMOTHERAPY WITH ONCOLYTIC VIROTHERAPY}

Chemotherapeutic drugs used in combination with OVs can potentiate their cytotoxic mechanisms (9), but may also act to remove barriers to successful oncolytic virotherapy. Counteracting immunological barriers can improve the persistence of viruses and/or weaken the immunosuppressive forces within the tumor microenvironment. In this section, we summarize how pharmaceutical immunomodulators may be used to promote adaptive antitumor immune responses induced by OVs.

\section{EVADING ANTIVIRAL IMMUNE RESPONSES}

Histone-deacetylase inhibitors (HDACi) are anti-inflammatory agents that can modulate immune responses to viral infection. By impeding the type I IFN response, a major component of the cellular innate antiviral response, HDACi's can enhance the spread and antitumor effects of OVs (102). In addition, HDACi's may also enhance OV efficacy through initial suppression of immune cell recruitment and inhibition of inflammatory cell pathways within NK cells (65). Similarly, a high throughput 
screen of pharmaceutical agents identified a novel drug (Vse1) that could enhance oncolytic virotherapy by disrupting the IFNinduced antiviral response and repressing antiviral gene transcripts (103). Another drug that can be used for immune suppression is cyclosphorine A, which markedly increased and prolonged the therapeutic effect of reovirus therapy of metastatic cancer (104, 105). However, the most common immunosuppressant drug used in the context of oncolytic virotherapy is cyclophosphamide (CPA); a chemotherapeutic alkylating agent that also induces apoptotic cell death. CPA has complex immunemodulating effects, affecting humoral and cellular mediators of both the innate and acquired immune responses. These immunosuppressive functions have been shown to enhance viral oncolysis and improve antitumor efficacy of $\operatorname{HSV}(83,106,107)$, Ad (108), measles virus (109), reovirus $(110,111)$, and VV (112). More specifically, at high doses, CPA has been shown to limit neutralizing antibody titers below the limit of detection during herpes virus hrR3 infection (106). Furthermore, in vivo depletion of complement significantly improved survival of HSV and CPA treated tumor-bearing rats (83). Global immunosuppression has also been reported to occur as a result of CPA therapy, including significant decreases in total white blood cell, lymphocyte, neutrophil, and monocyte counts in tumor-bearing mice. This was accompanied by significantly improved survival and decreased tumor volume in mice treated with both Ad and CPA relative to treatment with either therapy alone (108). Host lymphodepletion can enhance the therapeutic efficacy of OVs, as demonstrated by the reduction of antiviral antibody titers and subsequent promotion of viral persistence (113).

\section{COUNTERACTING THE IMMUNOSUPPRESSIVE TUMOR ENVIRONMENT}

Regulatory $\mathrm{T}$ cells and MDSC are TIL populations that are a major component of the immunosuppressive tumor environment. Most pharmaceutical strategies that counteract immune resistance mechanisms within the tumor are aimed at depleting these inhibitory immune cell populations. Reduction of Tregs in cancer patients has been demonstrated to occur following treatment with fludarabine and paclitaxel $(118,119)$. Other chemotherapeutic drugs shown to decrease Tregs and inhibit their suppressive ability include CPA, paclitaxel, and temozolomide and cisplatin treatment, which enhances antigen-specific $\mathrm{CD} 8^{+} \mathrm{T}$ cells in murine tumor models (114-117). In particular, CPA, paclitaxel, and temozolomide can successfully reduce Treg activity (120-122) when delivered as metronomic doses (i.e., repetitive, low doses). In the case of CPA, metronomic doses serve to minimize toxicity and avoid global immunosuppression resulting from administering a single, high dose. Comparison of metronomic and maximum tolerated doses of CPA revealed that deletion of proliferating tumor-specific CTLs occurred in both dosing schedules. However, at metronomic doses, slower kinetics of deletion and survival of cells with a CD43 "lo "memory" phenotype was observed, resulting in potent restimulatory capacity (122). This is supported by clinical evidence, in which metronomic CPA can deplete Tregs and restore $\mathrm{T}$ and $\mathrm{NK}$ cell effector function in advanced cancer patients (123). In the context of oncolytic virotherapy, preconditioning of mice with either CPA or anti-CD25 mAb to deplete Tregs enhances therapeutic benefits of oncolytic reovirus and VSV (111,
124). Furthermore, early clinical evaluation of metronomic CPA and oncolytic Ad combination treatment demonstrates improved antitumor efficacy, resulting from increased cytotoxic $\mathrm{T}$ cells and induced Th1 type immunity (125).

In healthy tissues, MDSCs play a protective role during inflammation to maintain homeostasis of pathogenic immune responses. However, accumulation of MDSCs in the tumor environment is also capable of promoting tumor growth by inhibiting antitumor effector $\mathrm{T}$ cell responses. They exert their effects through multiple immunomodulatory roles, such as upregulating the production of immune-suppressive factors (e.g., nitric oxide and reactive oxygen species), overexpressing anti-inflammatory cytokines (e.g., TGF$\beta$ and IL-10), suppressing proliferation and cytokine production by $\mathrm{T}$ cells and NK cells, and inducing apoptosis of $\mathrm{CD} 8^{+} \mathrm{T}$ cells (126). Furthermore, MDSCs can mediate the expansion of other immunosuppressive Treg and M2 populations (127-129). Numerous chemotherapeutic drugs have been used to deplete MDSCs, including gemcitabine, sunitinib, 5-FU, docetaxel, and retinoic acid (130-134). Combinations of OVs with various MDSC depleting drugs have been investigated at length, overall demonstrating improved survival in preclinical studies. The therapeutic benefits of using these OV-drug combinations depend on several factors, including the type of OV-drug combination used, the timing, frequency, and dosage of drug administration, and the cancer type targeted. However, given that these immunomodulatory drugs have other antitumoral effects, few studies have directly assessed their ability to deplete MDSCs in each context $(135,136)$. Notably, use of these drugs to deplete MDSCs can also positively or negatively affect oncolytic virotherapy. For instance, metronomic treatment of either gemcitabine or 5-Fu with oncolytic Ad, increases viral uptake by upregulating the expression of internalization receptors (137). Moreover, sunitinib negatively regulates the antiviral OAS-RNase L pathway, thus enhancing viral replication of VSV in tumors (138). In contrast, concurrent therapy of 5-Fu with HSV-1 inhibits virus replication and oncolysis (139). Therefore, optimization of these OV-drug combination strategies to benefit both the oncolytic and antitumor immune effects of OVs requires further investigation.

Given that chemotherapies have non-specific effects, some drugs can also modulate tumor cell immunogenicity to benefit oncolytic virotherapy. For example, paclitaxel can upregulate MHC class I expression and antigen-processing machinery components (140). 5' -aza-2'-deoxycytidine and 5-Fu have been shown to enhance tumor antigen expression (141-143), while Ara-C (cytosine arabinoside) treatment results in the induction of costimulatory molecules that provide a greater chance of effective immune activation $(144,145)$. Furthermore, both doxorubicin and Ara-C decreases the expression of immune checkpoint molecules, such as PD-L1, blocking their inhibitory effects on infiltrating $\mathrm{T}$ cells $(146,147)$. Some drugs, namely CPA, 5-Fu, and Dacarbazine, can sensitize tumor cells to $\mathrm{CD} 8^{+} \mathrm{T}$ cell-mediated apoptosis $(148,149)$, and thus may serve as ideal candidates for therapeutic combinations with various cancer immunotherapies.

EVALUATING THE LANDSCAPE OF OV-DRUG COMBINATIONS Tumor cell heterogeneity as a result of DNA instability promotes the natural selection of tumor progeny with greater proliferative 
capacity and invasive potential $(150,151)$. As a result, treatment methods that address a singular therapeutic strategy may be insufficient to completely eliminate tumor growth. OV-drug combinatorial strategies present countless different permutations, and consequently, numerous possibilities to mobilize multiple and simultaneous therapeutic approaches. However, previous studies that report synergistic outcomes from combining OVs with chemotherapy largely focus on a single therapeutic aspect, such as their effect on viral spread and persistence, cytotoxicity, or immunomodulation. As we become more familiar with how various chemotherapeutic drugs function, it is increasingly apparent that many drugs act in a multi-mechanistic fashion. In other words, chemotherapeutic agents can impact multiple biological processes, which in turn can further potentiate OV-drug interactions. For instance, rapamycin and its analogs have been shown to alter mTOR signaling to increase the tropism of OVs (152), inhibit angiogenesis (153), induce autophagy (32), and inhibit the function of M2 macrophages (154). HDACis such as Trichostatin A alter chromatin structure and regulate gene expression on an epigenetic level, leading to a wide range of biological effects like promoting tumor antigen presentation (155), improving tumor susceptibility to OVs (156-158), down-regulating the antiviral response (159), and targeting tumors and tumor vasculature (160). Lastly, receptor tyrosine kinase inhibitor sunitinib can downregulate antiviral pathways (138), deplete MDSCs (131), inhibit M2 macrophages (161), and reduce tumor vascularization (162). Therefore, rather than evaluating individual therapeutic strategies that are complementary to oncolytic viral activity, combinatorial strategies using chemotherapeutic drugs should take into account of their entire functional repertoire, in order to determine the best overall approach. However, given the complex, interconnected biological pathways that regulate viral infection and tumor growth, assessing OV-drug combinations is not a simple task.

\section{CHALLENGES OF COMBINATION THERAPY}

As previously mentioned, the biological pathways that OVs manipulate to support their replication are similar to those utilized by cancer cells to become increasingly malignant (e.g., defects in the IFN pathway, apoptotic-resistance, immune suppression). In fact, targeting certain pathways with chemotherapy will also, by association, compromise the replicative capacity of OVs. As a result, discernable conflicts between virus-enabled therapeutic strategies and drug-enabled therapeutic strategies may limit the extent to which the two can be combined. For example, viruses require actively dividing cells to maximize their replicative efficiency, while many anticancer agents are either cytotoxic or cytostatic with death-inducing or anti-proliferative effects, respectively (9). Furthermore, studies suggest that the leaky vasculature of tumors is exploited by viruses to successfully extravasate into the tumor site $(163,164)$. Some OVs can actually stimulate angiogenesis to increase vascular permeability in tumors (165). Thus, antiangiogenic therapy may thus adversely affect the localization of OVs to the tumor microenvironment. Finally, modulation of the host immune response through chemotherapy may conflict with the therapeutic function of the oncolytic virus. For instance, low dose CPA may remove immunosuppressive cells such as Tregs to improve vaccine-induced adaptive antitumor immune responses; however, it also promotes the antiviral immune response, leading to early viral clearance (166). Conversely, high dose CPA may enhance viral oncolysis through wide-spread immunosuppression of the innate and adaptive antiviral immune response, but also completely abrogate the antitumor immune response (167). These conflicting mechanisms (apoptosis vs. viral replication, antiangiogenesis vs. viral trafficking, antiviral immune responses vs. antitumor immune responses) are further compounded when we consider that drugs often regulate multiple biological host processes. Nevertheless, OV-drug combinations that demonstrate therapeutic incompatibility are still efficacious in some models. In these cases, it is likely that the number of beneficial interactions between OVs and drugs outweigh the number of detrimental effects, resulting in an overall enhanced therapeutic outcome. While current combinatorial strategies have been able to identify unique synergistic OV-drug platforms, the challenge going forward is to obtain a greater understanding of OV-drug interactions. Based on these exploratory findings, we will be able to identify optimal treatment conditions that minimize therapeutic trade-offs.

\section{SUCCESSFUL COMBINATION THERAPY IS CONTEXT-DEPENDENT}

As previously mentioned, seemingly incompatible OV-drug combinations have shown therapeutic efficacy because their positive effects outweigh their negative effects. Based on these initial studies, it is also apparent that some factors can tip the OV-drug dynamic in favor of enhanced cancer therapy in one context, but also have the reverse effects in another. For instance, concurrent administration of 5-FU has been shown to inhibit the replication of wild-type HSV-1 strain KOS (139); however, the same drug has been shown to actually enhance viral replication of NV1066 (HSV1 with a single copy of ICP0, ICP 4 , and $\gamma_{1} 34.5$ deleted) in pancreatic cancer cell lines (168). Interestingly, growth arrest and DNA damage as a result of 5-FU administration upregulates the expression of DNA damage-inducible protein GADD34, which bears significant homology with the deleted $\gamma_{1} 34.5$. As a consequence, GADD 34 can functionally replace $\gamma_{1} 34.5$, prevent premature shutoff of protein synthesis, and thus enhance viral replication (169). Another factor that is demonstrated to be context-dependent is the schedule and dosage of drug delivery given during OVdrug combination therapy. However, if their costs and benefits to oncolytic virotherapy are clear, we may adjust these variables for an optimized therapeutic outcome. For example, VEGF blockade through a variety of small-molecule chemotherapeutics decreases the tumor uptake of systemic oncolytic HSV, but can actually improve the treatment of sarcoma-bearing mice if anti-angiogenic therapy is given subsequent to virus administration (170).

Overall, specific strategies to optimize OV-drug combinations depend on the circumstances of the model system. To this point, we have previously shown that systemic vaccination with recombinant VSV encoding the xenogeneic TAA, human dopachrome tautomerase (hDCT), was unable to induce robust tumor-specific immunity because the host immune response was predominantly redirected toward viral antigens expressed on the vector. Therefore, by adopting a heterologous prime-boost system whereby mice were initially primed with recombinant Ad-hDCT and boosted with VSV-hDCT, substantive immunity was generated against the 
tumor, while the antiviral response to VSV was dampened (70). The HDACi, MS-275, is an ideal candidate for combination therapy with this prime-boost system because it has previously been shown to decrease IFN responsiveness in tumors, thus augmenting viral oncolysis. However, MS-275 is also immunosuppressive and resulted in abrogation of the priming response if given concurrently with Ad-hDCT. Alternatively, if drug treatment was given concurrently with VSV-hDCT, the boosting response was unaffected and over $60 \%$ of mice challenged with intracranial melanoma were cured (171). Since MS-275 is an HDACi; an epigenetic modifier that can modify the expression of numerous genes, its range of effects have not yet been fully elucidated. As such, many unknown functional properties may still exist, especially in the context of oncolytic virotherapy.

\section{CONCLUDING REMARIS}

War strategy dictates methods in which to arrange and maneuver military forces during armed conflicts. Using the available resources and landscape to your advantage is a key aspect to defeating the enemy. The analogy of OVs as fighters, "targeting" cancer cells and being "armed" with various genes, is commonplace in the literature. Its ability to induce antitumor immune responses is akin to the call for air support, bringing in additional fighters that can help to identify and target enemy forces. The introduction of chemotherapeutic drugs to the battlefield is then, chemical warfare; a wide-spread, indiscriminate weapon. With our various forces at hand, how do we determine the best strategy to defeat our opponents? As with any war strategy game, finding the best approach begins with knowing the enemy (type of cancer), knowing our forces (viruses, drugs, and immune cells), their strengths and weaknesses (function), and finally how they interact with each other on the battlefield (combination therapy). Before you make a move, you postulate various scenarios in which your opponent may attack, but also how you can take the advantage. In a similar fashion, to identify the most suitable approach to OV-drug combination therapies, we should adopt a broader perspective to the treatment of cancer. Then and only then, will we not only win some battles, but we may also win the war.

\section{REFERENCES}

1. Pol J. Oncolytic viruses: a step into cancer immunotherapy. Virus Adapt Treat (2012) 4:1-21. doi:10.2147/VAAT.S12980

2. Atherton MJ, Lichty BD. Evolution of oncolytic viruses: novel strategies for cancer treatment. Immunotherapy (2013) 5(11):1191-206. doi:10.2217/imt.13.123

3. Vacchelli E, Eggermont A, Sautes-Fridman C, Galon J, Zitvogel L, Kroemer G, et al. Trial watch: oncolytic viruses for cancer therapy. Oncoimmunology (2013) 2(6):e24612. doi:10.4161/onci.24612

4. Patel MR, Kratzke RA. Oncolytic virus therapy for cancer: the first wave of translational clinical trials. Transl Res (2013) 161(4):355-64. doi:10.1016/j.trsl. 2012.12.010

5. Buonaguro FM, Tornesello ML, Izzo F, Buonaguro L. Oncolytic virus therapies. Pharm Pat Anal (2012) 1(5):621-7. doi:10.4155/ppa.12.65

6. Moerdyk-Schauwecker M, Shah NR, Murphy AM, Hastie E, Mukherjee P, Grdzelishvili VZ. Resistance of pancreatic cancer cells to oncolytic vesicular stomatitis virus: role of type I interferon signaling. Virology (2013) 436(1):221-34. doi:10.1016/j.virol.2012.11.014

7. Forbes NE, Abdelbary H, Lupien M, Bell JC, Diallo JS. Exploiting tumor epigenetics to improve oncolytic virotherapy. Front Genet (2013) 4:184. doi:10.3389/fgene.2013.00184
8. Wennier ST, Liu J, McFadden G. Bugs and drugs: oncolytic virotherapy in combination with chemotherapy. Curr Pharm Biotechnol (2012) 13(9):1817-33. doi:10.2174/138920112800958850

9. Ottolino-Perry K, Diallo JS, Lichty BD, Bell JC, McCart JA. Intelligent design: combination therapy with oncolytic viruses. Mol Ther (2010) 18(2):251-63. doi:10.1038/mt.2009.283

10. Mendelsohn CL, Wimmer E, Racaniello VR. Cellular receptor for poliovirus: molecular cloning, nucleotide sequence, and expression of a new member of the immunoglobulin superfamily. Cell (1989) 56(5):855-65. doi:10.1016/ 0092-8674(89)90690-9

11. Merrill MK, Bernhardt G, Sampson JH, Wikstrand CJ, Bigner DD, Gromeier M. Poliovirus receptor CD155-targeted oncolysis of glioma. Neuro Oncol (2004) 6(3):208-17. doi:10.1215/S1152851703000577

12. Berno V, Porrini D, Castiglioni F, Campiglio M, Casalini P, Pupa SM, et al. The $67 \mathrm{kDa}$ laminin receptor increases tumor aggressiveness by remodeling laminin-1. Endocr Relat Cancer (2005) 12(2):393-406. doi:10.1677/erc.1.00870

13. Finkelshtein D, Werman A, Novick D, Barak S, Rubinstein M. LDL receptor and its family members serve as the cellular receptors for vesicular stomatitis virus. Proc Natl Acad Sci U S A (2013) 110(18):7306-11. doi:10.1073/pnas. 1214441110

14. Krishnamurthy S, Takimoto T, Scroggs RA, Portner A. Differentially regulated interferon response determines the outcome of Newcastle disease virus infection in normal and tumor cell lines. J Virol (2006) 80(11):5145-55. doi:10.1128/JVI.02618-05

15. Stojdl DF, Lichty B, Knowles S, Marius R, Atkins H, Sonenberg N, et al. Exploiting tumor-specific defects in the interferon pathway with a previously unknown oncolytic virus. Nat Med (2000) 6(7):821-5. doi:10.1038/77558

16. Stojdl DF, Lichty BD, tenOever BR, Paterson JM, Power AT, Knowles S, et al. VSV strains with defects in their ability to shutdown innate immunity are potent systemic anti-cancer agents. Cancer Cell (2003) 4(4):263-75. doi:10.1016/S1535-6108(03)00241-1

17. Noser JA, Mael AA, Sakuma R, Ohmine S, Marcato P, Lee PW, et al. The RAS/Raf1/MEK/ERK signaling pathway facilitates VSV-mediated oncolysis: implication for the defective interferon response in cancer cells. Mol Ther (2007) 15(8):1531-6. doi:10.1038/sj.mt.6300193

18. Wollmann G, Davis JN, Bosenberg MW, van den Pol AN. Vesicular stomatitis virus variants selectively infect and kill human melanomas but not normal melanocytes. J Virol (2013) 87(12):6644-59. doi:10.1128/JVI.03311-12

19. Rommelaere J, Geletneky K, Angelova AL, Daeffler L, Dinsart C, Kiprianova I, et al. Oncolytic parvoviruses as cancer therapeutics. Cytokine Growth Factor Rev (2010) 21(2-3):185-95. doi:10.1016/j.cytogfr.2010.02.011

20. Mansour M, Palese P, Zamarin D. Oncolytic specificity of Newcastle disease virus is mediated by selectivity for apoptosis-resistant cells. J Virol (2011) 85(12):6015-23. doi:10.1128/JVI.01537-10

21. Kruyt FA, Curiel DT. Toward a new generation of conditionally replicating adenoviruses: pairing tumor selectivity with maximal oncolysis. Hum Gene Ther (2002) 13(4):485-95. doi:10.1089/10430340252809784

22. Fukuda K, Abei M, Ugai H, Seo E, Wakayama M, Murata T, et al. E1A, E1B double-restricted adenovirus for oncolytic gene therapy of gallbladder cancer. Cancer Res (2003) 63(15):4434-40.

23. Mathis JM, Stoff-Khalili MA, Curiel DT. Oncolytic adenoviruses - selective retargeting to tumor cells. Oncogene (2005) 24(52):7775-91. doi:10.1038/sj. onc. 1209044

24. Chu RL, Post DE, Khuri FR, Van Meir EG. Use of replicating oncolytic adenoviruses in combination therapy for cancer. Clin Cancer Res (2004) 10(16):5299-312. doi:10.1158/1078-0432.CCR-0349-03

25. Wohlfahrt ME, Beard BC, Lieber A, Kiem HP. A capsid-modified, conditionally replicating oncolytic adenovirus vector expressing TRAIL leads to enhanced cancer cell killing in human glioblastoma models. Cancer Res (2007) 67(18):8783-90. doi:10.1158/0008-5472.CAN-07-0357

26. Zhao L, Dong A, Gu J, Liu Z, Zhang Y, Zhang W, et al. The antitumor activity of TRAIL and IL-24 with replicating oncolytic adenovirus in colorectal cancer. Cancer Gene Ther (2006) 13(11):1011-22. doi:10.1038/sj.cgt.7700969

27. Sathaiah M, Thirunavukkarasu P, O’Malley ME, Kavanagh MA, Ravindranathan R, Austin F, et al. Oncolytic poxvirus armed with Fas ligand leads to induction of cellular Fas receptor and selective viral replication in FasR-negative cancer. Cancer Gene Ther (2012) 19(3):192-201. doi:10.1038/cgt.2011.77 
28. van Beusechem VW, van den Doel PB, Grill J, Pinedo HM, Gerritsen WR. Conditionally replicative adenovirus expressing p53 exhibits enhanced oncolytic potency. Cancer Res (2002) 62(21):6165-71.

29. Ma J, He X, Wang W, Huang Y, Chen L, Cong W, et al. E2F promoterregulated oncolytic adenovirus with p16 gene induces cell apoptosis and exerts antitumor effect on gastric cancer. Dig Dis Sci (2009) 54(7):1425-31. doi:10.1007/s10620-008-0543-0

30. Fang L, Cheng Q, Li W, Liu J, Li L, Xu K, et al. Antitumor activities of an oncolytic adenovirus equipped with a double siRNA targeting Ki67 and hTERT in renal cancer cells. Virus Res (2014) 181:61-71. doi:10.1016/j.virusres.2013. 12.021

31. Li Y, Zhang B, Zhang H, Zhu X, Feng D, Zhang D, et al. Oncolytic adenovirus armed with shRNA targeting MYCN gene inhibits neuroblastoma cell proliferation and in vivo xenograft tumor growth. J Cancer Res Clin Oncol (2013) 139(6):933-41. doi:10.1007/s00432-013-1406-4

32. Meng S, Xu J, Wu Y, Ding C. Targeting autophagy to enhance oncolytic virus-based cancer therapy. Expert Opin Biol Ther (2013) 13(6):863-73. doi:10.1517/14712598.2013.774365

33. McFarlane S, Aitken J, Sutherland JS, Nicholl MJ, Preston VG, Preston CM. Early induction of autophagy in human fibroblasts after infection with human cytomegalovirus or herpes simplex virus 1. J Virol (2011) 85(9):4212-21. doi:10.1128/JVI.02435-10

34. Rodriguez-Rocha H, Gomez-Gutierrez JG, Garcia-Garcia A, Rao XM, Chen L, McMasters KM, et al. Adenoviruses induce autophagy to promote virus replication and oncolysis. Virology (2011) 416(1-2):9-15. doi:10.1016/j.virol.2011. 04.017

35. Alonso MM, Jiang H, Yokoyama T, Xu J, Bekele NB, Lang FF, et al. Delta24-RGD in combination with RAD001 induces enhanced anti-glioma effect via autophagic cell death. Mol Ther (2008) 16(3):487-93. doi:10.1038/sj.mt. 6300400

36. Jiang H, Gomez-Manzano C, Aoki H,Alonso MM, Kondo S, McCormick F, et al. Examination of the therapeutic potential of Delta-24-RGD in brain tumor stem cells: role of autophagic cell death. J Natl Cancer Inst (2007) 99(18):1410-4. doi:10.1093/jnci/djm102

37. Colunga AG, Laing JM, Aurelian L. The HSV-2 mutant DeltaPK induces melanoma oncolysis through nonredundant death programs and associated with autophagy and pyroptosis proteins. Gene Ther (2010) 17(3):315-27. doi:10.1038/gt.2009.126

38. Ito H, Aoki H, Kuhnel F, Kondo Y, Kubicka S, Wirth $\mathrm{T}$, et al. Autophagic cell death of malignant glioma cells induced by a conditionally replicating adenovirus. J Natl Cancer Inst (2006) 98(9):625-36. doi:10.1093/ jnci/djj161

39. Botta G, Passaro C, Libertini S, Abagnale A, Barbato S, Maione AS, et al. Inhibition of autophagy enhances the effects of E1A-defective oncolytic adenovirus dl922-947 against glioma cells in vitro and in vivo. Hum Gene Ther (2012) 23(6):623-34. doi:10.1089/hum.2011.120

40. Breitbach CJ, De Silva NS, Falls TJ, Aladl U, Evgin L, Paterson J, et al. Targeting tumor vasculature with an oncolytic virus. Mol Ther (2011) 19(5):886-94. doi:10.1038/mt.2011.26

41. Hou W, Chen H, Rojas J, Sampath P, Thorne SH. Oncolytic vaccinia virus demonstrates anti-angiogenic effects mediated by targeting of VEGF. Int J Cancer (2014). doi:10.1002/ijc.28747

42. Edukulla R, Woller N, Mundt B, Knocke S, Gurlevik E, Saborowski M, et al. Antitumoral immune response by recruitment and expansion of dendritic cells in tumors infected with telomerase-dependent oncolytic viruses. Cancer Res (2009) 69(4):1448-58. doi:10.1158/0008-5472.CAN-08-1160

43. Endo Y, Sakai R, Ouchi M, Onimatsu H, Hioki M, Kagawa S, et al. Virus-mediated oncolysis induces danger signal and stimulates cytotoxic $\mathrm{T}$ lymphocyte activity via proteasome activator upregulation. Oncogene (2008) 27(17):2375-81. doi:10.1038/sj.onc. 1210884

44. Melcher A, Parato K, Rooney CM, Bell JC. Thunder and lightning: immunotherapy and oncolytic viruses collide. Mol Ther (2011) 19(6):1008-16. doi:10.1038/mt.2011.65

45. Bridle BW, Hanson S, Lichty BD. Combining oncolytic virotherapy and tumour vaccination. Cytokine Growth Factor Rev (2010) 21(2-3):143-8. doi:10.1016/j. cytogfr.2010.02.009

46. Wong RJ, Chan MK, Yu Z, Kim TH, Bhargava A, Stiles BM, et al. Effective intravenous therapy of murine pulmonary metastases with an oncolytic herpes virus expressing interleukin 12. Clin Cancer Res (2004) 10(1 Pt 1):251-9. doi:10.1158/1078-0432.CCR-0197-3

47. Vigil A, Park MS, Martinez O, Chua MA, Xiao S, Cros JF, et al. Use of reverse genetics to enhance the oncolytic properties of Newcastle disease virus. Cancer Res (2007) 67(17):8285-92. doi:10.1158/0008-5472.CAN-07-1025

48. Post DE, Sandberg EM, Kyle MM, Devi NS, Brat DJ, Xu Z, et al. Targeted cancer gene therapy using a hypoxia inducible factor dependent oncolytic adenovirus armed with interleukin-4. Cancer Res (2007) 67(14):6872-81. doi:10.1158/0008-5472.CAN-06-3244

49. Choi IK, Lee JS, Zhang SN, Park J, Sonn CH, Lee KM, et al. Oncolytic adenovirus co-expressing IL-12 and IL-18 improves tumor-specific immunity via differentiation of T cells expressing IL-12Rbeta2 or IL-18Ralpha. Gene Ther (2011) 18(9):898-909. doi:10.1038/gt.2011.37

50. Cerullo V, Pesonen S, Diaconu I, Escutenaire S, Arstila PT, Ugolini M, et al. Oncolytic adenovirus coding for granulocyte macrophage colony-stimulating factor induces antitumoral immunity in cancer patients. Cancer Res (2010) 70(11):4297-309. doi:10.1158/0008-5472.CAN-09-3567

51. Koski A, Kangasniemi L, Escutenaire S, Pesonen S, Cerullo V, Diaconu I, et al. Treatment of cancer patients with a serotype 5/3 chimeric oncolytic adenovirus expressing GMCSF. Mol Ther (2010) 18(10):1874-84. doi:10.1038/mt. 2010.161

52. Senzer NN, Kaufman HL, Amatruda T, Nemunaitis M, Reid T, Daniels G, et al. Phase II clinical trial of a granulocyte-macrophage colony-stimulating factor-encoding, second-generation oncolytic herpesvirus in patients with unresectable metastatic melanoma. J Clin Oncol (2009) 27(34):5763-71. doi:10.1200/JCO.2009.24.3675

53. Kaufman HL, Bines SD. OPTIM trial: a phase III trial of an oncolytic herpes virus encoding GM-CSF for unresectable stage III or IV melanoma. Future Oncol (2010) 6(6):941-9. doi:10.2217/fon.10.66

54. Heo J, Reid T, Ruo L, Breitbach CJ, Rose S, Bloomston M, et al. Randomized dose-finding clinical trial of oncolytic immunotherapeutic vaccinia JX-594 in liver cancer. Nat Med (2013) 19(3):329-36. doi:10.1038/nm.3089

55. Kim JH, Oh JY, Park BH, Lee DE, Kim JS, Park HE, et al. Systemic armed oncolytic and immunologic therapy for cancer with JX-594, a targeted poxvirus expressing GM-CSF. Mol Ther (2006) 14(3):361-70. doi:10.1016/j.ymthe.2006. 05.008

56. Kanerva A, Nokisalmi P, Diaconu I, Koski A, Cerullo V, Liikanen I, et al. Antiviral and antitumor T-cell immunity in patients treated with GMCSF-coding oncolytic adenovirus. Clin Cancer Res (2013) 19(10):2734-44. doi:10.1158/1078-0432.CCR-12-2546

57. Kim MK, Breitbach CJ, Moon A, Heo J, Lee YK, Cho M, et al. Oncolytic and immunotherapeutic vaccinia induces antibody-mediated complementdependent cancer cell lysis in humans. Sci Transl Med (2013) 5(185):185ra63. doi:10.1126/scitranslmed.3005361

58. Dong J, McPherson CM, Stambrook PJ. Flt-3 ligand: a potent dendritic cell stimulator and novel antitumor agent. Cancer Biol Ther (2002) 1(5):486-9. doi:10.4161/cbt.1.5.161

59. Bernt KM, Ni S, Tieu AT, Lieber A. Assessment of a combined, adenovirusmediated oncolytic and immunostimulatory tumor therapy. Cancer Res (2005) 65(10):4343-52. doi:10.1158/0008-5472.CAN-04-3527

60. Barnard Z, Wakimoto H, Zaupa C, Patel AP, Klehm J, Martuza RL, et al. Expression of FMS-like tyrosine kinase 3 ligand by oncolytic herpes simplex virus type I prolongs survival in mice bearing established syngeneic intracranial malignant glioma. Neurosurgery (2012) 71(3):741-8. doi:10.1227/NEU. 0b013e318260fd73 discussion 8,

61. Li J, O’Malley M, Urban J, Sampath P, Guo ZS, Kalinski P, et al. Chemokine expression from oncolytic vaccinia virus enhances vaccine therapies of cancer. Mol Ther (2011) 19(4):650-7. doi:10.1038/mt.2010.312

62. Lapteva N, Aldrich M, Weksberg D, Rollins L, Goltsova T, Chen SY, et al. Targeting the intratumoral dendritic cells by the oncolytic adenoviral vaccine expressing RANTES elicits potent antitumor immunity. J Immunother (2009) 32(2):145-56. doi:10.1097/CJI.0b013e318193d31e

63. Li J, O’Malley M, Sampath P, Kalinski P, Bartlett DL, Thorne SH. Expression of CCL19 from oncolytic vaccinia enhances immunotherapeutic potential while maintaining oncolytic activity. Neoplasia (2012) 14(12):1115-21.

64. Reichel CA, Puhr-Westerheide D, Zuchtriegel G, Uhl B, Berberich N, Zahler S, et al. C-C motif chemokine CCL3 and canonical neutrophil attractants promote neutrophil extravasation through common and distinct 
mechanisms. Blood (2012) 120(4):880-90. doi:10.1182/blood-2012-01402164

65. Alvarez-Breckenridge CA, Yu J, Price R, Wei M, Wang Y, Nowicki MO, et al. The histone deacetylase inhibitor valproic acid lessens NK cell action against oncolytic virus-infected glioblastoma cells by inhibition of STAT5/T-BET signaling and generation of gamma interferon. J Virol (2012) 86(8):4566-77. doi:10.1128/JVI.05545-11

66. Bhat R, Dempe S, Dinsart C, Rommelaere J. Enhancement of NK cell antitumor responses using an oncolytic parvovirus. Int J Cancer (2011) 128(4):908-19. doi:10.1002/ijc. 25415

67. Galivo F, Diaz RM, Thanarajasingam U, Jevremovic D, Wongthida P, Thompson $\mathrm{J}$, et al. Interference of CD40L-mediated tumor immunotherapy by oncolytic vesicular stomatitis virus. Hum Gene Ther (2010) 21(4):439-50. doi:10.1089/hum.2009.143

68. Feder-Mengus C, Schultz-Thater E, Oertli D, Marti WR, Heberer M, Spagnoli GC, et al. Nonreplicating recombinant vaccinia virus expressing CD40 ligand enhances APC capacity to stimulate specific CD4+ and CD8+ T cell responses. Hum Gene Ther (2005) 16(3):348-60. doi:10.1089/hum.2005.16.348

69. Huang XF, Ren W, Rollins L, Pittman P, Shah M, Shen L, et al. A broadly applicable, personalized heat shock protein-mediated oncolytic tumor vaccine. Cancer Res (2003) 63(21):7321-9.

70. Bridle BW, Stephenson KB, Boudreau JE, Koshy S, Kazdhan N, Pullenayegum E, et al. Potentiating cancer immunotherapy using an oncolytic virus. Mol Ther (2010) 18(8):1430-9. doi:10.1038/mt.2010.98

71. Granot T, Yamanashi Y, Meruelo D. Sindbis viral vectors transiently deliver tumor-associated antigens to lymph nodes and elicit diversified antitumor CD8(+) T-cell immunity. Mol Ther (2014) 22(1):112-22. doi:10.1038/ mt.2013.215

72. Willmon CL, Saloura V, Fridlender ZG, Wongthida P, Diaz RM, Thompson J, et al. Expression of IFN-beta enhances both efficacy and safety of oncolytic vesicular stomatitis virus for therapy of mesothelioma. Cancer Res (2009) 69(19):7713-20. doi:10.1158/0008-5472.CAN-09-1013

73. Wongthida P, Diaz RM, Pulido C, Rommelfanger D, Galivo F, Kaluza K, et al. Activating systemic T-cell immunity against self tumor antigens to support oncolytic virotherapy with vesicular stomatitis virus. Hum Gene Ther (2011) 22(11):1343-53. doi:10.1089/hum.2010.216

74. Rommelfanger DM, Wongthida P, Diaz RM, Kaluza KM, Thompson JM, Kottke TJ, et al. Systemic combination virotherapy for melanoma with tumor antigenexpressing vesicular stomatitis virus and adoptive T-cell transfer. Cancer Res (2012) 72(18):4753-64. doi:10.1158/0008-5472.CAN-12-0600

75. Humphries C. Adoptive cell therapy: honing that killer instinct. Nature (2013) 504(7480):S13-5. doi:10.1038/504S13a

76. Vaha-Koskela MJ, Heikkila JE, Hinkkanen AE. Oncolytic viruses in cancer therapy. Cancer Lett (2007) 254(2):178-216. doi:10.1016/j.canlet.2007.02.002

77. Russell SJ, Peng KW, Bell JC. Oncolytic virotherapy. Nat Biotechnol (2012) 30(7):658-70. doi:10.1038/nbt.2287

78. Romagnani C, Della Chiesa M, Kohler S, Moewes B, Radbruch A, Moretta L, et al. Activation of human NK cells by plasmacytoid dendritic cells and its modulation by CD4+ T helper cells and CD4+ CD25hi T regulatory cells. Eur J Immunol (2005) 35(8):2452-8. doi:10.1002/eji.200526069

79. Dorner T, Radbruch A. Antibodies and B cell memory in viral immunity. Immunity (2007) 27(3):384-92. doi:10.1016/j.immuni.2007.09.002

80. Stoermer KA, Morrison TE. Complement and viral pathogenesis. Virology (2011) 411(2):362-73. doi:10.1016/j.virol.2010.12.045

81. Fisher KD, Stallwood Y, Green NK, Ulbrich K, Mautner V, Seymour LW. Polymer-coated adenovirus permits efficient retargeting and evades neutralising antibodies. Gene Ther (2001) 8(5):341-8. doi:10.1038/sj.gt.3301389

82. Massari I, Donnini A, Argentati K, Straino S, Mangoni A, Gaetano C, et al. Agedependent effects of repeated immunization with a first generation adenovirus vector on the immune response and transgene expression in young and old rats. Exp Gerontol (2002) 37(6):823-31. doi:10.1016/S0531-5565(02)00011-6

83. Ikeda K, Wakimoto H, Ichikawa T, Jhung S, Hochberg FH, Louis DN, et al. Complement depletion facilitates the infection of multiple brain tumors by an intravascular, replication-conditional herpes simplex virus mutant. J Virol (2000) 74(10):4765-75. doi:10.1128/JVI.74.10.4765-4775.2000

84. Pensiero MN, Wysocki CA, Nader K, Kikuchi GE. Development of amphotropic murine retrovirus vectors resistant to inactivation by human serum. Hum Gene Ther (1996) 7(9):1095-101. doi:10.1089/hum.1996.7.9-1095
85. Devaud C, John LB, Westwood JA, Darcy PK, Kershaw MH. Immune modulation of the tumor microenvironment for enhancing cancer immunotherapy. Oncoimmunology (2013) 2(8):e25961. doi:10.4161/onci.25961

86. Groh V, Wu J, Yee C, Spies T. Tumour-derived soluble MIC ligands impair expression of NKG2D and T-cell activation. Nature (2002) 419(6908):734-8. doi:10.1038/nature01112

87. Groh V, Smythe K, Dai Z, Spies T. Fas-ligand-mediated paracrine T cell regulation by the receptor NKG2D in tumor immunity. Nat Immunol (2006) 7(7):755-62. doi:10.1038/ni0906-1004a

88. Whiteside TL. Tumor-induced death of immune cells: its mechanisms and consequences. Semin Cancer Biol (2002) 12(1):43-50. doi:10.1006/scbi.2001.0402

89. Palazon A, Aragones J, Morales-Kastresana A, de Landazuri MO, Melero I. Molecular pathways: hypoxia response in immune cells fighting or promoting cancer. Clin Cancer Res (2012) 18(5):1207-13. doi:10.1158/1078-0432.CCR11-1591

90. Mendler AN, Hu B, Prinz PU, Kreutz M, Gottfried E, Noessner E. Tumor lactic acidosis suppresses CTL function by inhibition of p38 and JNK/c-Jun activation. Int J Cancer (2012) 131(3):633-40. doi:10.1002/ijc.26410

91. Lun X, Alain T, Zemp FJ, Zhou H, Rahman MM, Hamilton MG, et al. Myxoma virus virotherapy for glioma in immunocompetent animal models: optimizing administration routes and synergy with rapamycin. Cancer Res (2010) 70(2):598-608. doi:10.1158/0008-5472.CAN-09-1510

92. Smyth JW, Fleeton MN, Sheahan BJ, Atkins GJ. Treatment of rapidly growing K-BALB and CT26 mouse tumours using Semliki Forest virus and its derived vector. Gene Ther (2005) 12(2):147-59. doi:10.1038/sj.gt.3302390

93. Vaha-Koskela MJ, Kallio JP, Jansson LC, Heikkila JE, Zakhartchenko VA, Kallajoki MA, et al. Oncolytic capacity of attenuated replicative semliki forest virus in human melanoma xenografts in severe combined immunodeficient mice. Cancer Res (2006) 66(14):7185-94. doi:10.1158/0008-5472.CAN-05-2214

94. Cordaro TA, de Visser KE, Tirion FH, Graus YM, Haanen JB, Kioussis D, et al. Tumor size at the time of adoptive transfer determines whether tumor rejection occurs. Eur J Immunol (2000) 30(5):1297-307. doi:10.1002/(SICI)15214141(200005)30:5<1297::AID-IMMU1297>3.0.CO;2-C

95. Li ZY, Ni S, Yang X, Kiviat N, Lieber A. Xenograft models for liver metastasis: relationship between tumor morphology and adenovirus vector transduction. Mol Ther (2004) 9(5):650-7. doi:10.1016/j.ymthe.2004.01.021

96. Stohrer M, Boucher Y, Stangassinger M, Jain RK. Oncotic pressure in solid tumors is elevated. Cancer Res (2000) 60(15):4251-5.

97. Bilbao R, Bustos M, Alzuguren P, Pajares MJ, Drozdzik M, Qian C, et al. A blood-tumor barrier limits gene transfer to experimental liver cancer: the effect of vasoactive compounds. Gene Ther (2000) 7(21):1824-32. doi:10.1038/sj.gt. 3301312

98. Cairns R, Papandreou I, Denko N. Overcoming physiologic barriers to cancer treatment by molecularly targeting the tumor microenvironment. Mol Cancer Res (2006) 4(2):61-70. doi:10.1158/1541-7786.MCR-06-0002

99. Alain T, Kim M, Johnston RN, Urbanski S, Kossakowska AE, Forsyth PA, et al. The oncolytic effect in vivo of reovirus on tumour cells that have survived reovirus cell killing in vitro. Br J Cancer (2006) 95(8):1020-7. doi:10.1038/sj.bjc.6603363

100. Kim YT, Ganly I, Brown R, Stuart D. Acquired resistance to cytolysis of the E1B-attenuated adenovirus, dl1520, in ovarian tumour cell lines. Cancer Gene Ther (2003) 10(8):589-90.

101. Vitale I, Galluzzi L, Castedo M, Kroemer G. Mitotic catastrophe: a mechanism for avoiding genomic instability. Nat Rev Mol Cell Biol (2011) 12(6):385-92. doi:10.1038/nrm3115

102. Nguyen TL, Abdelbary H, Arguello M, Breitbach C, Leveille S, Diallo JS, et al. Chemical targeting of the innate antiviral response by histone deacetylase inhibitors renders refractory cancers sensitive to viral oncolysis. Proc Natl Acad Sci U S A (2008) 105(39):14981-6. doi:10.1073/pnas.0803988105

103. Diallo JS, Le Boeuf F, Lai F, Cox J, Vaha-Koskela M, Abdelbary H, et al. A high-throughput pharmacoviral approach identifies novel oncolytic virus sensitizers. Mol Ther (2010) 18(6):1123-9. doi:10.1038/mt.2010.67

104. Hirasawa K, Nishikawa SG, Norman KL, Coffey MC, Thompson BG, Yoon CS, et al. Systemic reovirus therapy of metastatic cancer in immune-competent mice. Cancer Res (2003) 63(2):348-53.

105. Smakman N, van der Bilt JD, van den Wollenberg DJ, Hoeben RC, Borel Rinkes $\mathrm{IH}, \mathrm{Kranenburg} \mathrm{O}$. Immunosuppression promotes reovirus therapy of colorectal liver metastases. Cancer Gene Ther (2006) 13(8):815-8. 
106. Ikeda K, Ichikawa T, Wakimoto H, Silver JS, Deisboeck TS, Finkelstein D, et al. Oncolytic virus therapy of multiple tumors in the brain requires suppression of innate and elicited antiviral responses. Nat Med (1999) 5(8):881-7. doi:10.1038/11320

107. Kambara H, Saeki Y, Chiocca EA. Cyclophosphamide allows for in vivo dose reduction of a potent oncolytic virus. Cancer Res (2005) 65(24):11255-8. doi:10.1158/0008-5472.CAN-05-2278

108. Thomas MA, Spencer JF, Toth K, Sagartz JE, Phillips NJ, Wold WS. Immunosuppression enhances oncolytic adenovirus replication and antitumor efficacy in the Syrian hamster model. Mol Ther (2008) 16(10):1665-73. doi:10.1038/ mt.2008.162

109. Ungerechts G, Springfeld C, Frenzke ME, Lampe J, Parker WB, Sorscher EJ, et al. An immunocompetent murine model for oncolysis with an armed and targeted measles virus. Mol Ther (2007) 15(11):1991-7. doi:10.1038/sj.mt.6300291

110. Qiao J, Wang H, Kottke T, White C, Twigger K, Diaz RM, et al. Cyclophosphamide facilitates antitumor efficacy against subcutaneous tumors following intravenous delivery of reovirus. Clin Cancer Res (2008) 14(1):259-69. doi:10.1158/1078-0432.CCR-07-1510

111. Kottke T, Thompson J, Diaz RM, Pulido J, Willmon C, Coffey M, et al. Improved systemic delivery of oncolytic reovirus to established tumors using preconditioning with cyclophosphamide-mediated Treg modulation and interleukin-2. Clin Cancer Res (2009) 15(2):561-9. doi:10.1158/1078-0432.CCR-08-1688

112. Lun XQ, Jang JH, Tang N, Deng H, Head R, Bell JC, et al. Efficacy of systemically administered oncolytic vaccinia virotherapy for malignant gliomas is enhanced by combination therapy with rapamycin or cyclophosphamide. Clin Cancer Res (2009) 15(8):2777-88. doi:10.1158/1078-0432.CCR-08-2342

113. Kim HS, Kim-Schulze S, Kim DW, Kaufman HL. Host lymphodepletion enhances the therapeutic activity of an oncolytic vaccinia virus expressing 41BB ligand. Cancer Res (2009) 69(21):8516-25. doi:10.1158/0008-5472.CAN09-2522

114. Ghiringhelli F, Larmonier N, Schmitt E, Parcellier A, Cathelin D, Garrido C, et al. CD4+CD25+ regulatory $\mathrm{T}$ cells suppress tumor immunity but are sensitive to cyclophosphamide which allows immunotherapy of established tumors to be curative. Eur J Immunol (2004) 34(2):336-44. doi:10.1002/eji. 200324181

115. Tseng CW, Hung CF, Alvarez RD, Trimble C, Huh WK, Kim D, et al. Pretreatment with cisplatin enhances E7-specific CD8+ T-Cell-mediated antitumor immunity induced by DNA vaccination. Clin Cancer Res (2008) 14(10):3185-92. doi:10.1158/1078-0432.CCR-08-0037

116. Lutsiak ME, Semnani RT, De Pascalis R, Kashmiri SV, Schlom J, Sabzevari $\mathrm{H}$. Inhibition of $\mathrm{CD} 4(+) 25+\mathrm{T}$ regulatory cell function implicated in enhanced immune response by low-dose cyclophosphamide. Blood (2005) 105(7):2862-8. doi:10.1182/blood-2004-06-2410

117. Ercolini AM, Ladle BH, Manning EA, Pfannenstiel LW, Armstrong TD, Machiels JP, et al. Recruitment of latent pools of high-avidity CD8(+) T cells to the antitumor immune response. J Exp Med (2005) 201(10):1591-602. doi:10.1084/jem.20042167

118. Zhang L, Dermawan K, Jin M, Liu R, Zheng H, Xu L, et al. Differential impairment of regulatory $\mathrm{T}$ cells rather than effector $\mathrm{T}$ cells by paclitaxel-based chemotherapy. Clin Immunol (2008) 129(2):219-29. doi:10.1016/j.clim.2008. 07.013

119. Beyer M, Kochanek M, Darabi K, Popov A, Jensen M, Endl E, et al. Reduced frequencies and suppressive function of $\mathrm{CD} 4+\mathrm{CD} 25$ hi regulatory $\mathrm{T}$ cells in patients with chronic lymphocytic leukemia after therapy with fludarabine. Blood (2005) 106(6):2018-25. doi:10.1182/blood-2005-02-0642

120. Banissi C, Ghiringhelli F, Chen L, Carpentier AF. Treg depletion with a low-dose metronomic temozolomide regimen in a rat glioma model. Cancer Immunol Immunother (2009) 58(10):1627-34. doi:10.1007/s00262-009-0671-1

121. Chen CA, Ho CM, Chang MC, Sun WZ, Chen YL, Chiang YC, et al. Metronomic chemotherapy enhances antitumor effects of cancer vaccine by depleting regulatory T lymphocytes and inhibiting tumor angiogenesis. Mol Ther (2010) 18(6):1233-43. doi:10.1038/mt.2010.34

122. Hermans IF, Chong TW, Palmowski MJ, Harris AL, Cerundolo V. Synergistic effect of metronomic dosing of cyclophosphamide combined with specific antitumor immunotherapy in a murine melanoma model. Cancer Res (2003) 63(23):8408-13.

123. Ghiringhelli F, Menard C, Puig PE, Ladoire S, Roux S, Martin F, et al. Metronomic cyclophosphamide regimen selectively depletes CD4+CD25+ regulatory $\mathrm{T}$ cells and restores $\mathrm{T}$ and $\mathrm{NK}$ effector functions in end stage cancer patients. Cancer Immunol Immunother (2007) 56(5):641-8. doi:10. 1007/s00262-006-0225-8

124. Kottke T, Galivo F, Wongthida P, Diaz RM, Thompson J, Jevremovic D, et al. Treg depletion-enhanced IL-2 treatment facilitates therapy of established tumors using systemically delivered oncolytic virus. Mol Ther (2008) 16(7):1217-26. doi: $10.1038 / \mathrm{mt} .2008 .83$

125. Cerullo V, Diaconu I, Kangasniemi L, Rajecki M, Escutenaire S, Koski A, et al. Immunological effects of low-dose cyclophosphamide in cancer patients treated with oncolytic adenovirus. Mol Ther (2011) 19(9):1737-46. doi:10. 1038/mt.2011.113

126. Gabrilovich DI, Nagaraj S. Myeloid-derived suppressor cells as regulators of the immune system. Nat Rev Immunol (2009) 9(3):162-74. doi:10.1038/nri2506

127. Serafini P, Mgebroff S, Noonan K, Borrello I. Myeloid-derived suppressor cells promote cross-tolerance in B-cell lymphoma by expanding regulatory $\mathrm{T}$ cells. Cancer Res (2008) 68(13):5439-49. doi:10.1158/0008-5472.CAN-07-6621

128. Sinha P, Clements VK, Bunt SK, Albelda SM, Ostrand-Rosenberg S. Crosstalk between myeloid-derived suppressor cells and macrophages subverts tumor immunity toward a type 2 response. J Immunol (2007) 179(2):977-83. doi:10.4049/jimmunol.179.2.977

129. Huang B, Pan PY, Li Q, Sato AI, Levy DE, Bromberg J, et al. Gr-1+CD115+ immature myeloid suppressor cells mediate the development of tumor-induced $\mathrm{T}$ regulatory cells and T-cell anergy in tumor-bearing host. Cancer Res (2006) 66(2):1123-31. doi:10.1158/0008-5472.CAN-05-1299

130. Suzuki E, Kapoor V, Jassar AS, Kaiser LR, Albelda SM. Gemcitabine selectively eliminates splenic Gr-1+/CD11b+ myeloid suppressor cells in tumor-bearing animals and enhances antitumor immune activity. Clin Cancer Res (2005) 11(18):6713-21. doi:10.1158/1078-0432.CCR-05-0883

131. Ko JS, Rayman P, Ireland J, Swaidani S, Li G, Bunting KD, et al. Direct and differential suppression of myeloid-derived suppressor cell subsets by sunitinib is compartmentally constrained. Cancer Res (2010) 70(9):3526-36. doi:10.1158/0008-5472.CAN-09-3278

132. Vincent J, Mignot G, Chalmin F, Ladoire S, Bruchard M, Chevriaux A, et al. 5-Fluorouracil selectively kills tumor-associated myeloid-derived suppressor cells resulting in enhanced T cell-dependent antitumor immunity. Cancer Res (2010) 70(8):3052-61. doi:10.1158/0008-5472.CAN-09-3690

133. Kodumudi KN, Woan K, Gilvary DL, Sahakian E, Wei S, Djeu JY. A novel chemoimmunomodulating property of docetaxel: suppression of myeloid-derived suppressor cells in tumor bearers. Clin Cancer Res (2010) 16(18):4583-94. doi:10.1158/1078-0432.CCR-10-0733

134. Kusmartsev S, Cheng F, Yu B, Nefedova Y, Sotomayor E, Lush R, et al. All-transretinoic acid eliminates immature myeloid cells from tumor-bearing mice and improves the effect of vaccination. Cancer Res (2003) 63(15):4441-9.

135. Esaki S, Goshima F, Kimura H, Murakami S, Nishiyama Y. Enhanced antitumoral activity of oncolytic herpes simplex virus with gemcitabine using colorectal tumor models. Int J Cancer (2013) 132(7):1592-601. doi:10.1002/ijc. 27823

136. Takehara Y, Satoh T, Nishizawa A, Saeki K, Nakamura M, Masuzawa M, et al. Anti-tumor effects of inactivated Sendai virus particles with an IL-2 gene on angiosarcoma. Clin Immunol (2013) 149(1):1-10. doi:10.1016/j.clim.2013.05. 019

137. Bhattacharyya M, Francis J, Eddouadi A, Lemoine NR, Hallden G. An oncolytic adenovirus defective in pRb-binding (dl922-947) can efficiently eliminate pancreatic cancer cells and tumors in vivo in combination with 5-FU or gemcitabine. Cancer Gene Ther (2011) 18(10):734-43. doi:10.1038/cgt.2011.45

138. Jha BK, Dong B, Nguyen CT, Polyakova I, Silverman RH. Suppression of antiviral innate immunity by sunitinib enhances oncolytic virotherapy. Mol Ther (2013) 21(9):1749-57. doi:10.1038/mt.2013.112

139. Kulu Y, Kawasaki H, Donahue JM, Kasuya H, Cusack JC, Choi EW, et al. Concurrent chemotherapy inhibits herpes simplex virus-1 replication and oncolysis. Cancer Gene Ther (2013) 20(2):133-40. doi:10.1038/cgt.2012.97

140. Kaneno R, Shurin GV, Kaneno FM, Naiditch H, Luo J, Shurin MR. Chemotherapeutic agents in low noncytotoxic concentrations increase immunogenic ity of human colon cancer cells. Cell Oncol (Dordr) (2011) 34(2):97-106. doi:10.1007/s13402-010-0005-5

141. Correale P, Aquino A, Giuliani A, Pellegrini M, Micheli L, Cusi MG, et al. Treatment of colon and breast carcinoma cells with 5-fluorouracil enhances expression of carcinoembryonic antigen and susceptibility to HLA-A $\left({ }^{*}\right) 02.01$ 
restricted, CEA-peptide-specific cytotoxic T cells in vitro. Int J Cancer (2003) 104(4):437-45. doi:10.1002/ijc.10969

142. Adair SJ, Hogan KT. Treatment of ovarian cancer cell lines with 5-aza-2'deoxycytidine upregulates the expression of cancer-testis antigens and class I major histocompatibility complex-encoded molecules. Cancer Immunol Immunother (2009) 58(4):589-601. doi:10.1007/s00262-008-0582-6

143. Fonsatti E, Nicolay HJ, Sigalotti L, Calabro L, Pezzani L, Colizzi F, et al. Functional up-regulation of human leukocyte antigen class I antigens expression by 5 -aza-2'-deoxycytidine in cutaneous melanoma: immunotherapeutic implications. Clin Cancer Res (2007) 13(11):3333-8. doi:10.1158/1078-0432. CCR-06-3091

144. Donepudi M, Raychaudhuri P, Bluestone JA, Mokyr MB. Mechanism of melphalan-induced B7-1 gene expression in P815 tumor cells. J Immunol (2001) 166(11):6491-9. doi:10.4049/jimmunol.166.11.6491

145. Sojka DK, Donepudi M, Bluestone JA, Mokyr MB. Melphalan and other anticancer modalities up-regulate B7-1 gene expression in tumor cells. J Immunol (2000) 164(12):6230-6. doi:10.4049/jimmunol.164.12.6230

146. Vereecque R, Saudemont A, Quesnel B. Cytosine arabinoside induces costimulatory molecule expression in acute myeloid leukemia cells. Leukemia (2004) 18(7):1223-30. doi:10.1038/sj.leu.2403391

147. Ghebeh H, Lehe C, Barhoush E, Al-Romaih K, Tulbah A, Al-Alwan M, et al. Doxorubicin downregulates cell surface B7-H1 expression and upregulates its nuclear expression in breast cancer cells: role of B7-H1 as an anti-apoptotic molecule. Breast Cancer Res (2010) 12(4):R48. doi:10.1186/bcr2605

148. van der Most RG, Currie AJ, Cleaver AL, Salmons J, Nowak AK, Mahendran $\mathrm{S}$, et al. Cyclophosphamide chemotherapy sensitizes tumor cells to TRAILdependent CD8 T cell-mediated immune attack resulting in suppression of tumor growth. PLoS One (2009) 4(9):e6982. doi:10.1371/journal.pone. 0006982

149. Yang S, Haluska FG. Treatment of melanoma with 5-fluorouracil or dacarbazine in vitro sensitizes cells to antigen-specific CTL lysis through perforin/granzyme- and Fas-mediated pathways. J Immunol (2004) 172(7):4599-608. doi:10.4049/jimmunol.172.7.4599

150. Breitbach CJ, Burke J, Jonker D, Stephenson J, Haas AR, Chow LQ, et al. Intravenous delivery of a multi-mechanistic cancer-targeted oncolytic poxvirus in humans. Nature (2011) 477(7362):99-102. doi:10.1038/nature10358

151. Sobol PT, Boudreau JE, Stephenson K, Wan Y, Lichty BD, Mossman KL. Adaptive antiviral immunity is a determinant of the therapeutic success of oncolytic virotherapy. Mol Ther (2011) 19(2):335-44. doi:10.1038/mt.2010.264

152. Stanford MM, Barrett JW, Nazarian SH, Werden S, McFadden G. Oncolytic virotherapy synergism with signaling inhibitors: rapamycin increases myxoma virus tropism for human tumor cells. J Virol (2007) 81(3):1251-60. doi:10.1128/JVI.01408-06

153. Homicsko K, Lukashev A, Iggo RD. RAD001 (everolimus) improves the efficacy of replicating adenoviruses that target colon cancer. Cancer Res (2005) 65(15):6882-90. doi:10.1158/0008-5472.CAN-05-0309

154. Chen W, Ma T, Shen XN, Xia XF, Xu GD, Bai XL, et al. Macrophage-induced tumor angiogenesis is regulated by the TSC2-mTOR pathway. Cancer Res (2012) 72(6):1363-72. doi:10.1158/0008-5472.CAN-11-2684

155. Khan AN, Magner WJ, Tomasi TB. An epigenetic vaccine model active in the prevention and treatment of melanoma. J Transl Med (2007) 5:64. doi:10.1186/1479-5876-5-64

156. Otsuki A, Patel A, Kasai K, Suzuki M, Kurozumi K, Chiocca EA, et al. Histone deacetylase inhibitors augment antitumor efficacy of herpes-based oncolytic viruses. Mol Ther (2008) 16(9):1546-55. doi:10.1038/mt.2008.155

157. Katsura T, Iwai S, Ota Y, Shimizu H, Ikuta K, Yura Y. The effects of trichostatin A on the oncolytic ability of herpes simplex virus for oral squamous cell carcinoma cells. Cancer Gene Ther (2009) 16(3):237-45. doi:10.1038/cgt.2008.81

158. MacTavish H, Diallo JS, Huang B, Stanford M, Le Boeuf F, De Silva N, et al. Enhancement of vaccinia virus based oncolysis with histone deacetylase inhibitors. PLoS One (2010) 5(12):e14462. doi:10.1371/journal.pone.0014462

159. Genin P, Morin P, Civas A. Impairment of interferon-induced IRF-7 gene expression due to inhibition of ISGF3 formation by trichostatin A. J Virol (2003) 77(12):7113-9. doi:10.1128/JVI.77.12.7113-7119.2003
160. Liu TC, Castelo-Branco P, Rabkin SD, Martuza RL. Trichostatin A and oncolytic HSV combination therapy shows enhanced antitumoral and antiangiogenic effects. Mol Ther (2008) 16(6):1041-7. doi:10.1038/mt.2008.58

161. Xin H, Zhang C, Herrmann A, Du Y, Figlin R, Yu H. Sunitinib inhibition of Stat 3 induces renal cell carcinoma tumor cell apoptosis and reduces immunosuppressive cells. Cancer Res (2009) 69(6):2506-13. doi:10.1158/0008-5472. CAN-08-4323

162. Kottke T, Hall G, Pulido J, Diaz RM, Thompson J, Chong H, et al. Antiangiogenic cancer therapy combined with oncolytic virotherapy leads to regression of established tumors in mice. J Clin Invest (2010) 120(5):1551-60. doi:10.1172/JCI41431

163. Matsumura Y, Maeda H. A new concept for macromolecular therapeutics in cancer chemotherapy: mechanism of tumoritropic accumulation of proteins and the antitumor agent smancs. Cancer Res (1986) 46(12 Pt 1):6387-92.

164. Fang J, Nakamura H, Maeda H. The EPR effect: unique features of tumor blood vessels for drug delivery, factors involved, and limitations and augmentation of the effect. Adv Drug Deliv Rev (2011) 63(3):136-51. doi:10.1016/j.addr.2010. 04.009

165. Aghi M, Rabkin SD, Martuza RL. Angiogenic response caused by oncolytic herpes simplex virus-induced reduced thrombospondin expression can be prevented by specific viral mutations or by administering a thrombospondinderived peptide. Cancer Res (2007) 67(2):440-4. doi:10.1158/0008-5472.CAN06-3145

166. Bartlett DL, Liu Z, Sathaiah M, Ravindranathan R, Guo Z, He Y, et al. Oncolytic viruses as therapeutic cancer vaccines. Mol Cancer (2013) 12(1):103. doi:10.1186/1476-4598-12-103

167. Prestwich RJ, Harrington KJ, Pandha HS, Vile RG, Melcher AA, Errington F. Oncolytic viruses: a novel form of immunotherapy. Expert Rev Anticancer Ther (2008) 8(10):1581-8. doi:10.1586/14737140.8.10.1581

168. Eisenberg DP, Adusumilli PS, Hendershott KJ, Yu Z, Mullerad M, Chan MK, et al. 5-Fluorouracil and gemcitabine potentiate the efficacy of oncolytic herpes viral gene therapy in the treatment of pancreatic cancer. J Gastrointest Surg (2005) 9(8):1068-77. doi:10.1016/j.gassur.2005.06.024 discussion 77-9,

169. Braidwood LGS, Graham A, Conner J. Oncolytic herpes viruses, chemotherapeutics, and other cancer drugs. Oncolytic Virother (2013) 2:57-74. doi:10. 2147/OV.S52601

170. Eshun FK, Currier MA, Gillespie RA, Fitzpatrick JL, Baird WH, Cripe TP. VEGF blockade decreases the tumor uptake of systemic oncolytic herpes virus but enhances therapeutic efficacy when given after virotherapy. Gene Ther (2010) 17(7):922-9. doi:10.1038/gt.2010.82

171. Bridle BW, Chen L, Lemay CG, Diallo JS, Pol J, Nguyen A, et al. HDAC inhibition suppresses primary immune responses, enhances secondary immune responses, and abrogates autoimmunity during tumor immunotherapy. $\mathrm{Mol}$ Ther (2013) 21(4):887-94. doi:10.1038/mt.2012.265

Conflict of Interest Statement: The authors declare that the research was conducted in the absence of any commercial or financial relationships that could be construed as a potential conflict of interest.

Received: 19 March 2014; paper pending published: 21 May 2014; accepted: 28 May 2014; published online: 11 June 2014.

Citation: Nguyen A, Ho L and Wan Y (2014) Chemotherapy and oncolytic virotherapy: advanced tactics in the war against cancer. Front. Oncol. 4:145. doi: 10.3389/fonc.2014.00145

This article was submitted to Tumor Immunity, a section of the journal Frontiers in Oncology.

Copyright () 2014 Nguyen, Ho and Wan. This is an open-access article distributed under the terms of the Creative Commons Attribution License (CC BY). The use, distribution or reproduction in other forums is permitted, provided the original author $(s)$ or licensor are credited and that the original publication in this journal is cited, in accordance with accepted academic practice. No use, distribution or reproduction is permitted which does not comply with these terms. 